\title{
A FMOLS Analysis of FDI Flows to Latin America
}

\author{
Miguel D. Ramirez \\ Correspondence: Miguel D. Ramirez, Professor of Economics in the Department of Economics, Trinity College, \\ Hartford, CT, USA.
}

Received: January 18, 2019

Accepted: February 15, 2019 Available online: February 24, 2019

doi:10.11114/aef.v6i2.4088

URL: https://doi.org/10.11114/aef.v6i2.4088

\begin{abstract}
This paper estimates a panel FDI investment function that seeks to identify some of the major economic and institutional determinants of net FDI flows to nine major Latin American countries during the 1980-2014 period. First, it utilizes Dunning's OLI model to identify some of the major economic and institutional determinants of FDI. Second, the paper provides an overview of FDI flows to Latin America during the 1990-2017 period, with particular emphasis on their contribution to the financing of gross fixed capital formation. Third, an economic rationale is provided for the included variables and their expected signs. Fourth, the paper reports estimates for a Fully Modified Ordinary least Squares (FMOLS) panel regression designed to explain the variation in FDI flows to Latin America during the 1980-2014 period. The estimates suggest that real GDP (a proxy for market size), credit provided by the private banking sector, government expenditures on education, and the level of economic freedom as measured by the Fraser Institute have a positive and significant effect. On the other hand, public investment spending, the volatility of real GDP and the real exchange rate have a negative and significant effect on FDI flows. The panel unit root and (Pedroni) panel cointegration tests suggest that there is a stable, long-term relationship among the included variables; i.e., the selected variables in the reported regressions are cointegrated over the relevant time period.
\end{abstract}

JEL Classifications: C22, C23, F40, FO10, O50

Keywords: foreign direct investment (FDI), gross fixed capital formation, fully modified ordinary squares (FMOLS), panel unit root tests, pedroni cointegration test, remittances of FDI profits and dividends

\section{Introduction}

During the 1990s most Latin American nations adopted a market-based, outward-oriented strategy of economic growth and development. This market-based strategy has been associated with a dramatic opening of capital markets and a rapid increase in foreign direct investment (FDI) flows to the region. For example, net FDI flows to the countries of Latin America and the Caribbean rose dramatically from $\$ 8.4$ billion in 1990 to $\$ 77.2$ billion in 2000 and almost 100 billion in 2008, before falling during the recessionary years of 2009 and 2010 (see UNCTAD, 2015). However, in the wake of the dramatic economic recovery experienced by South America during the 2010-12 period, these net flows are estimated to have risen sharply to $\$ 153.5$ billion in 2011 (see UNCTAD, 2015; and ECLAC, 2016). From a relative standpoint, Latin America's share of FDI flows to developing countries rose from 29 percent in 1995 to an-all time high of 39.5 percent in 2000, before falling to 28.9 percent during the recession year of 2009 , and then rebounding, respectively, to 30.5 and 32 percent in 2010 and 2011-12. The region's share fell again to 25.3 percent in 2013-14 following a significant decline in cross-border mergers and acquisitions in Central America and lower commodity prices which reduced investment in extractive industries, particularly in South America(see UNCTAD, 2015, pp. 58-62). Another reason for the fall in the share of FDI flows to the region in recent years is explained by the completion of major privatizations in industry, banking, and mining in the region (see UNCTAD, 2012). The recent resurgence in FDI inflows to the region was led primarily by investments in natural resource endowments (copper, nickel, and oil), mergers and acquisitions, and so-called "Greenfield investments" in manufacturing and services in Brazil, Chile and Mexico, and it remains to be seen whether it can be sustained beyond the immediate future [see UNCTAD 2015, pp. 58-64].

The economic rationale for opening the region's capital markets to both portfolio and FDI flows resides in the belief that foreign capital can help bridge the gap between savings and investment in capital-scarce economies and, particularly in the case of FDI flows, bring modern technology and managerial knowhow that promotes economic growth and encourages the development of financial markets. The empirical evidence also suggests that FDI flows are 
less volatile because they involve long-term commitments that often lead to the establishment of foreign subsidiaries as well as the acquisition of existing entities via international mergers (see Bosworth and Collins, 1999; Kumar, 2007; and Montecinos and Cordero, 2010). FDI has been referred to as the "good cholesterol" because it is less likely than portfolio investments to leave emerging markets at the first hint of economic trouble as evidenced by their relative stability and growth during the financial and economic crises that have buffeted emerging markets during the 1990s and beyond (see Kumar, 2007; and Cypher, 2014). Finally, to the extent that FDI flows are directed to the establishment of new enterprises in leading manufacturing sectors--so-called "Greenfield investments"--as opposed to the buying of existing firms via mergers and acquisitions--so-called "Brownfield investments"--the economic impact of these flows on long-term regional growth and development is likely to be greater (see Zhuang, 2012).

In view of the importance of this topic, this paper estimates a panel FDI investment function via Fully Modified Ordinary Least Squares (FMOLS) that seeks to identify some of the major economic and institutional determinants of FDI flows to nine major Latin American countries during the 1980-2014 period. It is organized as follows: First, the paper follows Dunning's OLI model in order to identify some of the major economic and institutional determinants of FDI. Second, the paper gives an overview of FDI flows to Latin America during the 1990-2017 period, with particular emphasis on their contribution to the financing of gross capital formation. Third, an empirical model for FDI flows to Latin America is outlined and an economic rationale is provided for the included variables and their expected signs. Fourth, the paper undertakes panel unit root tests on the relevant variables and a panel (Pedroni) cointegration test to determine whether there is a stable, long-term relationship among the included (panel) variables; next, it reports FMOLS estimates for the long-term panel regressions. Finally, the paper summarizes the major findings and offers some policy prescriptions for attracting FDI flows to the region and enhancing their positive direct and indirect effects.

\section{Conceptual Framework}

John Dunning (1988) argues that transnational corporations (TNCs) invest abroad when three sets of relative advantages are present, viz., ownership, location, and internalization advantages. First, the establishment of subsidiaries gives the parent firms exclusive ownership rights over patents, trademarks, commercial secrets and production processes, thereby effectively denying access to both foreign and domestic competitors. Second, they generate for TNC affiliates locational advantages that arise from direct access to growing markets and lower unit labor costs, reduced transportation and communication costs, avoidance of tariffs and non-tariff barriers, and direct access to raw materials, low-cost unskilled labor, and intermediate products that are indispensable for the production of certain goods. Third, Dunning points to the advantages TNCs derive from internalizing certain operations because utilizing market mechanisms are relatively more burdensome and costly. For instance, many TNCs establish a subsidiaries abroad and assume directly the contractual and administrative costs associated with research, development, production, and marketing of a given product or service, thus avoiding the transaction costs associated with leasing licenses and securing patents to undertake production or hiring the services of advertising agencies to market and distribute their products. Spitaler (1971) argue that firms choose direct investment rather than licensing primarily because of the non-excludability property of new knowledge capital; viz., it is too costly for TNCs to prevent licensees from "defecting" and copying the new technology at little cost and setting up their own domestic firms in direct competition with the TNCs.

Thus, a fourth determinant of FDI is based on strategic considerations. The decision by TNCs to undertake investments abroad for strategic reasons has been greatly facilitated in recent years by the globalization of financial markets which, in turn, has significantly reduced entry barriers associated with large fixed costs. For example, Aliber (1970) and others contend that large TNCs, with their greater [and cheaper] access to financial capital, have both the ability and the incentive to enter foreign markets to preserve market share and profits which are threatened by other indigenous and foreign firms. For similar strategic and tax reasons, TNCs are able to give the appearance of repatriating a lower profit without reducing their actual profit by manipulating intra-firm transfer pricing (see Mortimore, 2003). For example, TNCs have the incentive to charge high prices for inputs to subsidiaries operating in high-tax countries and charge low prices for the output which these subsidiaries sell back to the parent company. In this manner the TNC is able to attain a number of strategic objectives, viz., it is able to keep its reported profit rate low and thus reduce its overall corporate taxes; it is also likely to avoid bad publicity and potential expropriation via accusations of price gouging from the host country government (see Cypher and Dietz, 2014).

The nature and scope of government policies are also a highly important factor in determining whether FDI flows to developing economies such as Chile or Costa Rica. For example, FDI is likely to be attracted to countries where governments ensure an adequate provision of economic and social infrastructure in the form of paved roads, ports, airfields, relatively cheap energy supplies, and a well-educated and disciplined work force. In this connection, the literature points to skilled workers and adequate physical infrastructure as important determinants of FDI flows because it enables TNCs to strengthen both their ownership and locational advantages, thus allowing them to expand their market not only in the host country but the region as well (see Ramasamy and Young, 2004). FDI flows are likely to be 
induced by policies that lead to the establishment of a legal-institutional framework that is conducive to business activity, namely, one that reduces the transactions costs associated with negotiating contracts, improves information about the quality of goods and services, and makes sure that the parties to a formal agreement honor their commitments (see Yeager, 1999).

Finally, a country's exchange rate policy plays a key role in altering its relative attractiveness to net FDI inflows. In this connection, economists are not entirely of one mind when it comes to the optimal exchange rate strategy to pursue. For example, some argue that a policy that keeps the real exchange rate undervalued relative to that of its key investment partners is, ceteris paribus, likely to enhance FDI flows because it artificially reduces the unit costs of the country=s factors of production and thus enables investors to make a significantly larger investment in terms of the domestic currency. Others contend that a policy that leads to a real appreciation of the domestic currency is likely to encourage FDI inflows because it enhances the foreign currency (dollar) value of the remittances of profits and dividends back to the parent company (see De Mello, Jr., 1997; and Cypher, 2014). In light of the conflicting views in the literature on the impact of the exchange rate on FDI flows, it is best, from a policy standpoint, to pursue a credible strategy that maintains the country $=\mathrm{s}$ real exchange rate in line with that of its key trading and investment partners.

\section{FDI Flows to Latin America During the 1990-2017 Period}

Following the debt crisis, net FDI inflows (gross inflows minus outflows) to Latin America and the Caribbean declined in absolute terms during the first half of the 1980s, after which they began to increase steadily during the second half of the 1980s and posted a dramatic surge during the decade of the 1990s. For example, they averaged close to $\$ 56$ billion during the 1991-99 period (see ECLAC, 2006). An increasing proportion of these funds were directed to emerging nations such as China, India, as well as the major countries of Latin America and the Caribbean. For example, net FDI flows to Argentina, Chile, Brazil , Mexico, and Peru averaged close to $\$ 52$ billion during the 1996-2001 period, before falling to $\$ 37$ billion in 2002, and $\$ 25.7$ billion in 2003 as a result of the relatively mild 2001 U.S. recession. Figure 1 below shows that with the recovery of economic activity in the United States after 2003, FDI flows to the countries of Latin American and the Caribbean resumed at a brisk pace as attested by the rise in net inflows to $\$ 57$ billion in 2005, $\$ 96$ billion in 2007 , and slightly over $\$ 100$ billion in 2008 , before falling sharply in 2009 to $\$ 72.2$ billion in the aftermath of the Great Recession of 2007-09 ( ECLAC 2016, Table A1-10, p. 97; and UNCTAD, 2015). Figure 1 below also reveals that the abrupt fall in net FDI flows to Latin America and the Caribbean in 2009was quickly reversed in 2010 when the region, led by Argentina, Brazil, Chile, Mexico, Peru, and Uruguay, experienced a sharp inflow of funds thanks, in part, to rising commodity prices and aggressive Keynesian-style countercyclical policies in countries such as China, India, Argentina, Brazil, Chile, and Ecuador--relative to their developed counterparts in Europe and the United States. According to ECLAC (2016), the surge in net inflows to the region that began in 2010 continued into 2011--attaining in that year an all-time high of $\$ 153.5$ billion--and thereafter ranging between $\$ 142$ to $\$ 148$ billion for the 2012 and 2014 period, before falling sharply in 2015 and 2016 to $\$ 137$ and 131 billion, respectively. The rapid rise in FDI inflows that began in 2010 can be traced to a sharp improvement in the region's terms of trade resulting from relatively higher prices for key primary commodities such as copper, nickel, and petroleum induced by the strong demand for commodities by China and the United States; robust internal demand in the form of consumption and investment spending (particularly in Brazil, Chile Colombia and Ecuador); and last but not least, the high rate of return on capital investments in the region (see UNCTAD, 2012, p 53). The fall in FDI inflows to Latin America and the Caribbean in 2015 and 2016 can be traced to a number of internal and external factors. For example, the sharp fall in the demand for primary commodities by China and the European Union due to their slower growth; a 72 percent decrease in cross-border mergers and acquisitions in Central America and the Caribbean, and the exhaustion of countercyclical (populist) policies in countries such as Argentina, Brazil, and Venezuela. 


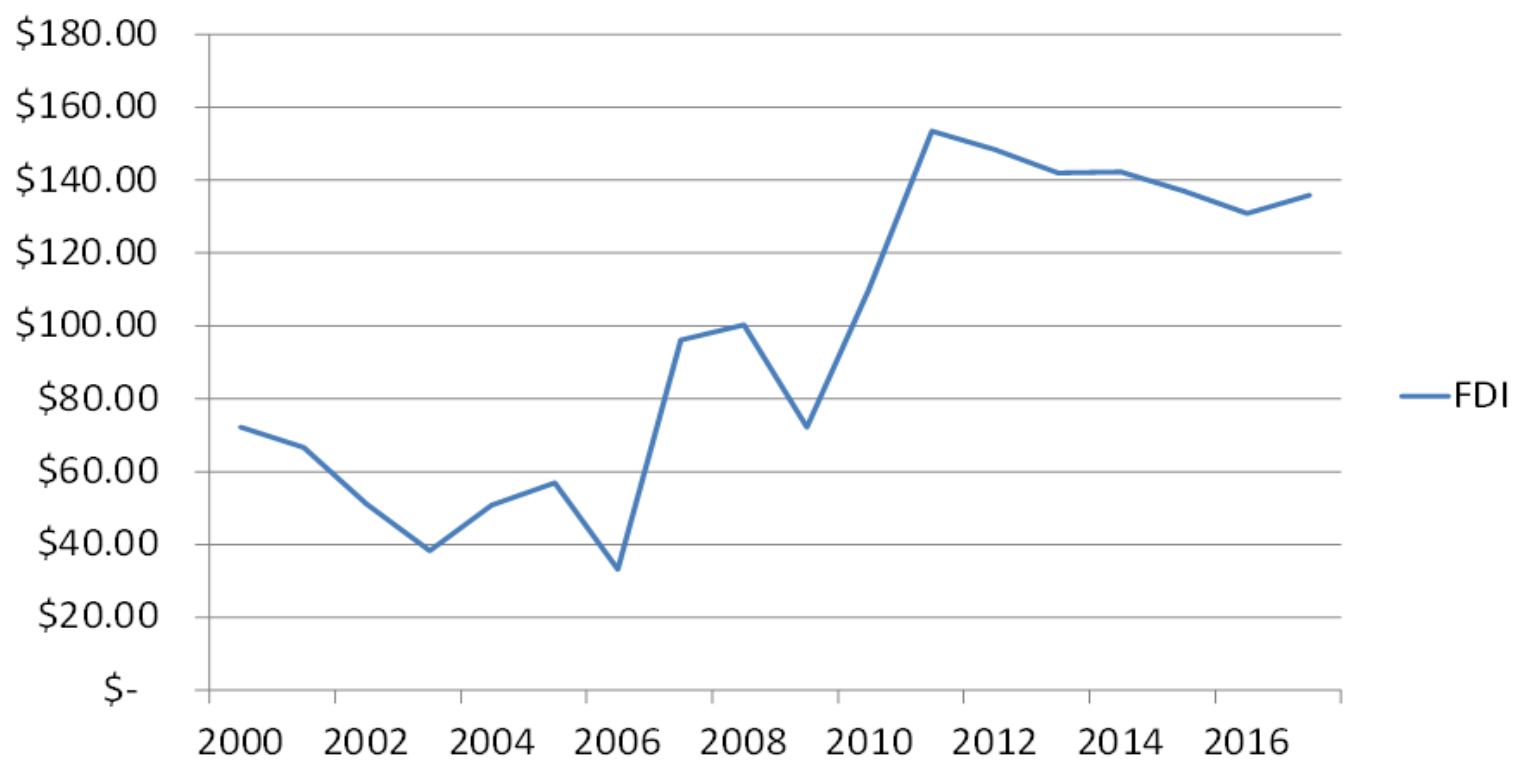

Figure 1. Net FDI Flows to Latin America, 2000-2017 (Billions of dollars)

More importantly, from the standpoint of economic growth and development, the increase in FDI inflows has been driven by robust investments in Greenfield investments in manufacturing and services, particularly in South America (Brazil and Chile) and Mexico - in the latter it is primarily directed to the auto parts and assembly sector and manufacturing in general. Accordin to UNCTAD (2012), gross investments in new enterprises in leading sectors ofLatin America.

The importance of these net inflows is better appreciated by focusing on their recent evolution relative to GDP and the gross fixed capital formation of the major countries of the region, given FDI's important role in financing private capital formation. Figure 2 below show that net FDI inflows as a proportion of the region's GDP were quite significant during the 2000-2017 period. For example, with the exception of the years 2006 and 2009, these net flows have represented at least 2 percent of the region's GDP, and during 2010-17 they averaged a respectable 2.7 percent (with some years at or close to 3 percent of regional GDP).

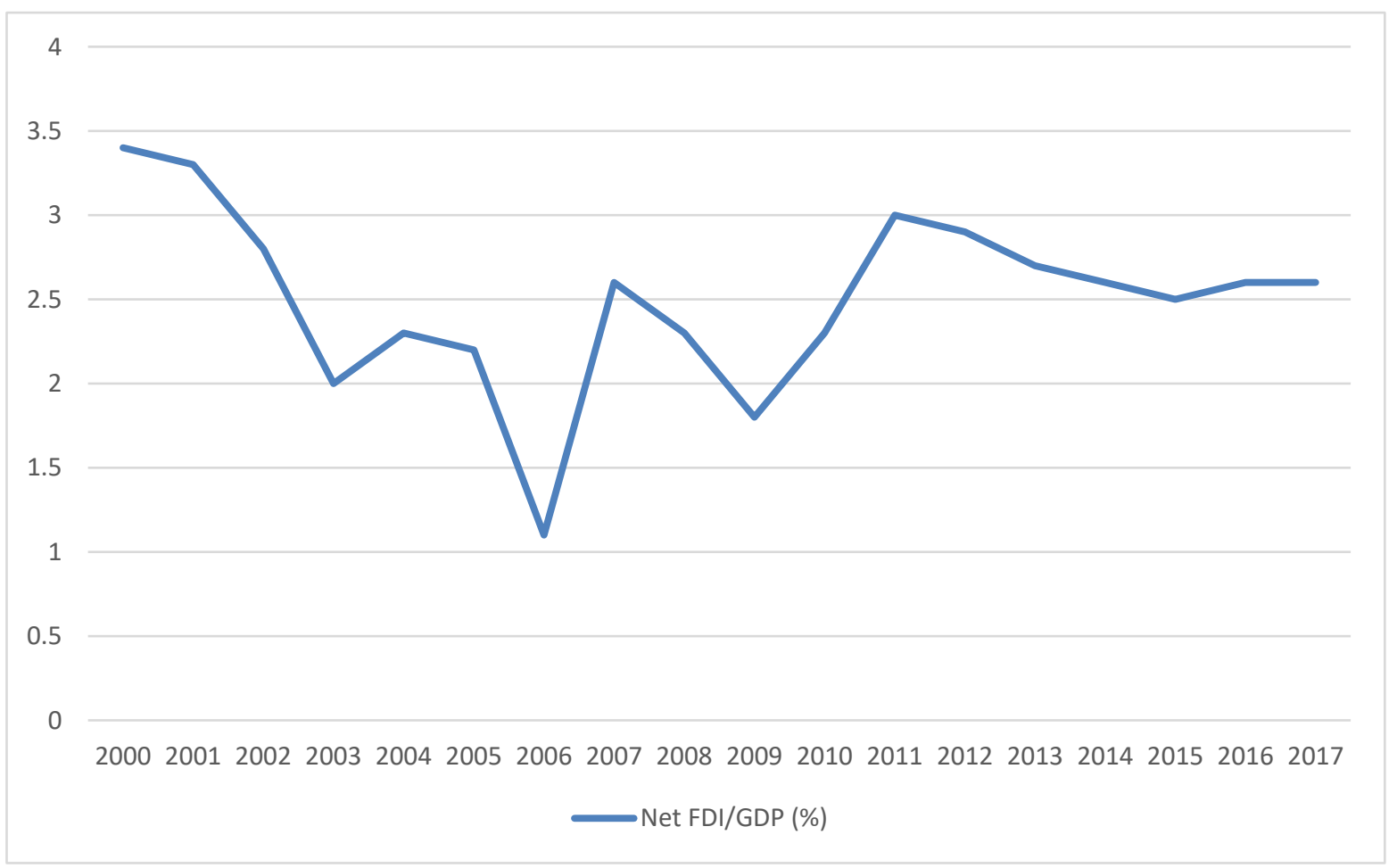

Figure 2. Net FDI Flows as a Percentage of Latin America's Gross Domestic Product: 2000-2017 
Table 1 below reports net FDI flows as a percentage of gross fixed capital formation during the decades of the 2000s; it reveals that, beginning in2003, FDI inflows to the major countries of Latin America represented a significant percentage of their gross fixed capital formation; and in the cases of Colombia, Costa Rica, Chile, Ecuador, Peru, and Uruguay these flows reached at least one fifth of their gross fixed capital formation during the 2003-2012 period. For Latin America as a whole, net FDI inflows as a proportion of gross capital formation rose impressively

Table 1. Selected Latin American Nations: Net Foreign Direct Investment Flows ${ }^{\mathrm{a}}$ as a Percentageof Gross Fixed Capital Formation, 2000-2015

\begin{tabular}{lccccccccccccccccccc}
\hline Country & $\mathbf{2 0 0 0}$ & $\mathbf{2 0 0 1}$ & $\mathbf{2 0 0 2}$ & $\mathbf{2 0 0 3}$ & $\mathbf{2 0 0 4}$ & $\mathbf{2 0 0 5}$ & $\mathbf{2 0 0 6}$ & $\mathbf{2 0 0 7}$ & $\mathbf{2 0 0 8}$ & $\mathbf{2 0 0 9}$ & $\mathbf{2 0 1 0}$ & $\mathbf{2 0 1 1}$ & $\mathbf{2 0 1 2}$ & $\mathbf{2 0 1 3}$ & $\mathbf{2 0 1 4}$ & $\mathbf{2 0 1 5}$ \\
\hline Argentina & 25.3 & 8.4 & 17.6 & 9.6 & 15.0 & 11.0 & 11.1 & 10.1 & 11.8 & 9.8 & 16.9 & 13.0 & 21.2 & 12.9 & 4.9 & 16.4 \\
Brazil & 28.4 & 22.7 & 19.6 & 11.3 & 16.0 & 9.0 & 10.3 & 14.0 & 13.9 & 18.9 & 14.1 & 18.1 & 17.2 & 10.8 & 14.9 & 14.9 & \\
Chile & 22.9 & 31.4 & 17.8 & 28.2 & 39.2 & 18.3 & 24.3 & 33.0 & 35.6 & 34.1 & 31.0 & 19.3 & 12.3 & 12.7 & 17.6 & 13.5 & \\
Colombia & 21.1 & 21.8 & 17.6 & 16.1 & 17.1 & 18.0 & 18.8 & 18.7 & 17.6 & 12.2 & 10.0 & 8.3 & 19.9 & 10.2 & 13.5 & 8.6 \\
Costa Rica & 14.4 & 15.3 & 20.7 & 17.2 & 22.9 & 18.3 & 32.5 & 33.8 & 30.3 & 22.7 & 20.7 & 29.9 & 21.8 & 29.4 & 30.4 & 30.7 \\
Ecuador & 32.7 & 45.2 & 23.0 & 25.1 & 16.5 & 6.0 & 3.3 & 1.9 & 8.1 & 2.8 & 4.0 & 3.9 & 3.2 & 3.7 & 3.5 & 6.9 \\
Mexico & 13.7 & 20.7 & 12.1 & 9.4 & 16.7 & 8.0 & 10.0 & 13.9 & 11.0 & 8.8 & 9.3 & 5.0 & -0.9 & 14.1 & 8.1 & 9.3 \\
Peru & 6.8 & 11.6 & 21.6 & 12.3 & 12.8 & 18.3 & 18.6 & 22.3 & 19.5 & 25.9 & 18.1 & 18.5 & 25.4 & 18.6 & 16.2 & 18.2 \\
Uruguay & 10.3 & 14.0 & 15.6 & 39.4 & 22.3 & 39.0 & 41.1 & 29.9 & 32.6 & 25.4 & 28.9 & 30.5 & 26.2 & 30.0 & 20.8 & 8.8 \\
Venezuela & 25.9 & 16.7 & 3.8 & 20.4 & 7.7 & 5.0 & 2.1 & 2.6 & 1.5 & 1.3 & 2.1 & 13.1 & 2.9 & 3.7 & -1.6 & 5.0 \\
\hline $\begin{array}{l}\text { Latin } \\
\text { America }\end{array}$ & $\mathbf{2 0 . 7}$ & $\mathbf{2 0 . 0}$ & $\mathbf{1 5 . 4}$ & $\mathbf{1 3 . 0}$ & $\mathbf{4 . 1}$ & $\mathbf{1 5 . 1}$ & $\mathbf{1 5 . 6}$ & $\mathbf{2 0 . 8}$ & $\mathbf{2 3 . 5}$ & $\mathbf{1 8 . 9}$ & $\mathbf{1 7 . 6}$ & $\mathbf{1 4 . 4}$ & $\mathbf{1 3 . 4}$ & $\mathbf{1 2 . 5}$ & $\mathbf{1 2 . 7}$ & $\mathbf{1 2 . 9}$ \\
\hline
\end{tabular}

Source: Computed by author from UNCTAD, World Investment Report, 2012, Annex Table I.1, p.171; ECLAC, Economic Survey of Latin America and the Caribbean, 2012, Tables A2 and A6, pp. 119-20; and ECLAC, Statistical

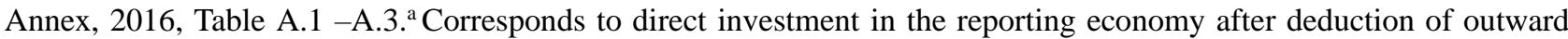
direct investment by residents of that country.A negative sign means that outward direct investment exceeds inward direct investment in the reporting economy.

From an average of only 8.5 percent during the $1987-97$ period to a high of 20.7 percent in 2000 , before falling somewhat to 15.4 percent in 2002 (see Table 1). Clearly, during the early 2000s, Latin America exhibited an impressive record of attracting FDI flows to finance gross fixed capital formation (see UNCTAD, 2012; and ECLAC, 2012). Notable performers during this period are Argentina, Chile, Costa Rica, Ecuador, Mexico, Uruguay, and Venezuela. However, as noted above, following the relatively mild U.S. recession of 2001 and the serious economic crisis in Argentina in 2001-2002, FDI inflows as a percentage of gross fixed capital formation fell sharply to a decennial low of 13 percent in 2003. However, Table 1 shows that after 2003 the share of FDI inflows rebounded sharply to almost 24 percent in 2008, and despite the aftermath of the Great Recession of 2007-09, they proved to be resilient and fell only to approximately 18 percent in 2009-10. Still, in recent years, Table 1 shows that during the 2011-2015 period there has been a fall in the share of net FDI inflows in gross fixed capital formation to an average of 13.2 percent due to the deceleration of growth and investment in the region alluded to above. In some notable cases, such as Mexico and Venezuela, net foreign direct investment has diverted resources away from the financing of gross fixed capital formation-even before deducting profits and dividends (see the years 2012 and 2014 for Mexico and Venezuela, respectively).

Critics of the role of TNCs contend that FDI inflows divert resources away from capital formation because they generate substantial reverse flows in the form of remittances of profit and dividends to the parent companies. They also argue that the reported reverse flows are probably a gross underestimate because of the widespread practice of intra-firm transfer pricing by TNCs, i.e., under-voicing of subsidiaries' exports and over-invoicing of their imports of capital goods and technology (see Cypher and Dietz, 2014; Montecinos and Cordero, 2010; and Ram and Zhang, 2002). , in order to assess the net contribution of FDI to the financing of private capital formation, one must subtract from gross (or net) FDI inflows the repatriation of profits and dividends to the parent companies, often residing in the U.S. for many of the countries in question. Support for this contention can be found in the following figures: profit and dividend remittances by Latin America and the Caribbean to the developed countries more than doubled between 2004 
and 2012, from $\$ 33.6$ billion to $\$ 158$ billion (see ECLAC, 2012, Table 2.2.1.1, p. 97; and ECLAC, 2016, Table A1.1, p. 88). ${ }^{1}$ That is, during the year 2012 the outflow of resources (in the form of profits and dividends) from the region exceeded the inflow in the form of net FDI by practically $\$ 10$ billion. Moreover, from an individual country standpoint, the remittance of profits and dividends in recent years is even more alarming. For example, consider the case of Chile, a country that has been widely praised for its pursuit of market-based, outward-oriented policies and which has over the 2000-2017 period attracted vast amounts of net FDI inflows, particularly in view of its relatively small size.

Nevertheless, given its highly liberal policies towards the repatriation of profits, it has also experienced a huge reverse flow of profits and dividends in recent years. For example, the repatriation of net profits on FDI rose from $\$ 2.1$ billion in 2002 to $\$ 10.3$ billion in 2005 and a staggering $\$ 20$ billion in 2007, and thereafter fell to $\$ 9.5$ and $\$ 6.6$ billion in 2014 and 2015, respectively. To put these figures in perspective, the outflow of net profits in 2014 alone represented 41.3 percent of the gross inflows of FDI into the country that year, and 70.2 percent of net inflows of FDI at $\$ 9.4$ billion (ECLAC, 2016, p. 97; and UNCTAD, 2016)! In fact, relative to the country's gross inflows of FDI, Chile's repatriation of net profits on FDI during the 2002-2015 period averaged 76 percent (computed from ECLAC, 2015; and UNCTAD, 2016).

Net profits on FDI during the 2002-2015 period averaged 76 percent [computed from UNCTAD, 2016]. Table 2 (Part B) below shows that the contribution of net FDI inflows adjusted for the remittances of profits and dividends (and expressed as a proportion of fixed capital formation), is far less than that advertised by the unadjusted figures in Part A. It even reveals that net FDI actually diverted resources away from the financing of capital formation during the 2002-2007 period. In fact, Chile's remittances of profits and dividends during the 2000-2015 period far exceeded those of Mexico's, a much larger country which received far more net FDI inflows over the same interval. ${ }^{2}$

Table 2. Part A. Chile: Net FDI Flows as a Percentage of Gross Fixed Capital Formation, 1990-2015

\begin{tabular}{lllllllllllllllll}
\hline 1990 & 1992 & 1993 & 1995 & 1997 & 1998 & 1999 & 2000 & 2001 & 2002 & 2003 & 2005 & 2007 & 2009 & 2011 & 2013 & 2015 \\
\hline 8.3 & 7.5 & 7.2 & 12.1 & 27.9 & 22.9 & $54.3^{1}$ & 22.9 & 31.4 & 17.8 & 28.2 & 18.3 & 33.0 & 34.1 & 19.3 & 12.7 & 13.5 \\
\hline
\end{tabular}

Part B. Chile: FDI Inflows adjusted for the Remittance of Profits and Dividends as a Percentage of Gross Fixed Capital Formation, 1990-2015²

\begin{tabular}{lcccccccrcccccccc}
\hline 1990 & 1992 & 1993 & 1995 & 1997 & 1998 & 1999 & 2000 & 2001 & 2002 & 2003 & 2005 & 2007 & 2009 & 2011 & 2013 & 2015 \\
\hline 4.8 & -2.1 & 0.8 & 10.9 & 17.4 & 17.8 & 43.8 & 8.1 & 2.1 & -0.5 & -11.3 & -9.3 & -17.8 & 2.2 & 4.9 & 8.4 & 3.1 \\
\hline
\end{tabular}

Source: United Nations, World Investment Report, 2016. New York: United Nations, 2016, Annex Tables 1 and 2; ECLAC, Statistical Yearbook for Latin America and the Caribbean, 2006. Santiago, Chile: United Nations, 2006, Table 2.1.1.54, p. 132, and Table 2.1.1.57, p. 135; and ECLAC, Statistical Annex, 2016, Tables A1-A3. ${ }^{1}$ The unusually high figure for Chile is the coincidental result of a doubling of FDI inflows and a steep drop in gross fixed capital formation in 1999. ${ }^{2} \mathrm{~A}$ negative value indicates that profits and dividend payments exceeded FDI inflows for that year, thereby diverting resources away from fixed capital formation.

In any event, the surge in net FDI flows to the countries of Latin America during the 1990-2011 period were due, partly, to "push factors" in the industrialized countries, such as relatively low rates of return on investments during the early 1990s (and early 2000s). In addition, "pull factors" played an important, such as the partial reduction of the debt burden via the use of Brady bonds, expanding consumer markets, natural resource endowments, the implementation of credible macroeconomic stabilization policies and market-based structural reform programs[see Green, 2005; UNCTAD, 2012]. The latter include privatization and debt conversion programs, the liberalization of the tradable sector, the removal of overly restrictive FDI legislation concerning the repatriation of profits and prior authorization of investments, as well as eliminating sectoral restrictions such as local content and export requirements (see Agosin, 1995; UNCTAD, 2012).

Only time will tell if these reforms are sustainable in the long run from the standpoint of economic development in view

${ }^{1}$ Between 2000 and 2010, FDI inward stock in Latin America (1990 dollars) more than tripled from \$461.1 billion to $\$ 1,584.5$. Recent data indicates that the surge has continued into the 2000s, with the inward stock of FDI rising to $\$ 1,960.1$ billion in 2016 ! (UNCTAD, 2017, Table 2, p. 228). In relative terms, FDI inward stock as a percentage of GDP rose from 10.5 percent in 1990 to 23.6 percent in 2000, and 44.4 percent in 2013 - the latest year for which we have reliable data (see UNCTAD, 2017, Annex Table 7; and ECLAC, 2016.) The remarkable increase in FDI inward stock during the 1990s is far greater than that of the entire Alost decade@ of the 1980 s.

${ }^{2}$ ECLAC (2016) reports that profit remittances on FDI for Mexico averaged $\$ 9$ billion for the 2000-2012 period, while those for Chile averaged $\$ 13.5$ billion, or one and a half times as much. In fact, there were five years (2006-2008, and 2010-12) when profit remittances on FDI for Chile approximated or exceeded $\$ 20$ billion, while in the case of Mexico, for the same years (2006-2008, and 2011-12), they ranged between $\$ 10$ and $\$ 14$ billion. These reverse flows are not only large in absolute terms but relative to GDP and GFCF as well. 
of the lingering effects of the Great Recession of 2007-09, the sharp drop in commodity prices beginning in 2014, and the emergence of China and India as major destinations for FDI flows (see Stiglitz, 2003). ${ }^{3}$

\section{Empirical Model and Results}

\subsection{Model}

Following the lead of Agosin (1995), Chowdhury and Mavrotas (2006), De Mello, Jr (1997), Ramasamy and Yeung (2004), Ramirez (2005), Ros (1994), and Vadlamannati and Tamazian (2009), this study estimates a foreign direct investment (FDI) function that pools data for nine major Latin American nations: Argentina, Brazil, Chile, Colombia, Costa Rica, Ecuador, Mexico, Peru, and Uruguay over the 1980-2014 period. ${ }^{4}$ The panel regression includes the effect of a number of relevant variables whose economic rationale for inclusion is discussed below. The simplest formulation is:

$$
(\mathrm{FDIR})_{\mathrm{it}}=\mathrm{f}\left[(\mathrm{LGDP})_{\mathrm{it-i}}, \mathrm{REX}_{\mathrm{it}-\mathrm{I}}, \mathrm{DS}_{\mathrm{it}-\mathrm{i},}, \mathrm{GIR}_{\mathrm{it}-\mathrm{i}, \mathrm{i}} \mathrm{GED}_{\mathrm{it}-\mathrm{i}}, \mathrm{CR}_{\mathrm{it}-\mathrm{i}}, \mathrm{EF}_{\mathrm{it}} ; \mathrm{D}_{\mathrm{i}}\right]+\varepsilon_{\mathrm{it}}
$$

the regressand, FDIR, is the ratio of net FDI inflows to real GDP it includes standard regressors such as the log of real GDP [and the period standard deviations (SDGDP)] , the real exchange rate (REX) [and the period standard deviation (SDREX)], and the ratio of debt service payments to exports of goods and services (DS). Other relevant variables are public investment spending as a proportion of GDP (GIR), government expenditures on education as a percentage of GDP (GED) as a proxy for human capital, credit channeled by the banking system to the private sector (CR) as a percentage of GDP the economic freedom index $(\mathrm{EF})$ generated by the Fraser Institute, and dummy variables $\left(\mathrm{D}_{\mathrm{i}}\right)$ to explain the variation in FDI flows to Latin America during the 1980-2015 period. ${ }^{5} \varepsilon_{\mathrm{it}}$ is a normally distributed error term.

\subsection{Economic Rationale}

Latin America's potential market size is proxied by the lagged value of the log of real GDP (LGDP) and its sign is expected to be positive. The period standard deviation of real GDP, SDLGDP, is included in the model to capture the impact of GDP volatility on net FDI flows to the region. It is hypothesized that this variable will have a negative effect on net FDI flows to the region because the more volatile real GDP is, the greater the uncertainty for foreign investors in terms of anticipated internal aggregate demand, volume of sales, and profits.

The real exchange rate is included in the model because it is the most important link between economic policy and international competitiveness and, as explained in Section II, it is expected to have an indeterminate sign in the Latin America case (see Agosin, 1995). ${ }^{6}$ A ceteris paribus real depreciation of the domestic currency (a rise in REX) should increase the profitability of export-oriented sectors and, ceteris paribus, induce net FDI flows to them. On the other hand, a real depreciation of the domestic currency reduces the (dollar) value of the remittances of profits and dividends back to the parent company, thereby reducing the real rate of return on the parent company's initial (dollar) investment. The latter should reduce net FDI flows to the country, ceteris paribus.

The standard deviation of the real exchange rate, $\mathrm{SD}(\mathrm{REX})$ is also included (separately) in the model to capture the impact of exchange rate volatility on FDI flows to the region. It is expected that, ceteris paribus, this variable will have a negative effect on net FDI flows to the regions because the more volatile REX is, the greater the uncertainty for foreign investors when it comes to the expected costs and profits in both the tradeable and non-tradeable sectors.

\footnotetext{
${ }^{3}$ Data for 2016 suggest that FDI inflows to China (excluding Hong Kong) are estimated at US\$133.7 billion which, if confirmed, would fall slightly below the total inflows to Latin America and the Caribbean as a whole at an estimated US\$139.7 billion. In fact, China's FDI inflows in 2016 made it the second largest recipient of FDI inflows in the World, still far behind the United States at US\$391.1 billion (see UNCTAD, 2017, pp. 222-223).

${ }^{4}$ Data for the variables in question were obtained from various issues of ECLAC and the World Data Bank (World Development Indicators). The period had to be shortened because several years of data were missing for variables such as public investment spending as a percentage of GDP, public spending on education as a percentage of GDP, and credit provided by the banking sector to private sector as a percentage of GDP.

${ }^{5}$ Agosin (1995) reports estimates for a simple regression model that tries to explain the variation in FDI flows to Chile during the 1975-93 period. He finds that both the level of real GDP in constant dollars and the real depreciation of the exchange have a positive and statistically significant effect on FDI flows. He also includes a dummy variable to capture the adoption of the debt conversion program (Chapter XIX), and finds that it also has a positive and statistically significant impact on FDI flows. The major problem with this otherwise interesting and thought-provoking paper is that the author does not undertake a unit root and cointegration analysis of the FDI investment relationship.

${ }^{6}$ It would be preferable to use a more direct measure of costs such as unitary labor costs. Unfortunately, data on unit labor costs for the period under review is not available for all the countries in the sample in a consistent and reliable form.
} 
The debt service payments- to- exports ratio, was included to measure country risk; viz., the higher the ratio, the greater the probability that a BOP crisis will emerge which may lead to the imposition of restrictions on profit and dividend remittances, thereby depressing FDI flows to the country. It is anticipated to have a negative and statistically significant effect on inward net FDI flows.

Public investment as a proportion of GDP is included because, ceteris paribus, countries with better roads, bridges, and ports are, on average, more attractive to foreign investors because of lower production and transportation costs. Due to lack of data, this variable also includes investments undertaken by state-owned enterprises (SOEs) in key sectors of the economy such as industry, banking, mining, energy, and agriculture. If these investments are undertaken by heavily subsidized and/or inefficient SOEs , then government investment may directly (and indirectly via competition for scarce funds) "crowd out" both private domestic and foreign investment (see Erden and Holcombe, 2005). Moreover, during the period in question, many of the countries of Latin America pursued draconian IMF-sponsored stabilization and adjustment programs that led to unprecedented across-the-board cuts in public investment in economic and social infrastructure while, at the same time, they liberalized their economies to capital flows, including FDI flows. In view of this, the impact of this variable on net FDI inflows is indeterminate.

The model also includes government expenditures on education as a percentage of GDP as crude proxy for the quality of the country's human capital. The rationale for including the GED variable is that, ceteris paribus, the higher the level of education in any given country, the more attractive it is to foreign investors both from a cost standpoint (lower unit labor costs) and a demand-side perspective (greater purchasing power and more informed consumers) (see Ramasamy and Yeung, 2004). The credit variable (CR) is expected to have positive impact on net FDI flows because, in many Latin American nations, the quantity constraint is binding in terms of financing the construction of new plant, machinery, and equipment. In other words, a greater pool of investible resources should, ceteris paribus, ease the financing constraint of both foreign and domestic investors (see Erden and Holcombe, 2005).

In order to assess whether the countries in question have a legal-institutional framework conducive to business activity, and are thus relatively more attractive to foreign (and domestic) investors, the economic freedom index generated by the Fraser Institute was included in the model. That is, countries with greater economic freedom have a legal-institutional framework that is more conducive to business activity and economic growth than countries that adopt policies that restrict economic freedom. This index is a summary measure of a number components of "economic freedom" such as monetary policy and price stability, the top marginal tax rate, legal structure and property rights, viability of contracts, and the rule of law. The index has a scale that ranges from 1 to 10 , where a score of 10 represents the highest attainable level of economic freedom. ${ }^{7}$ It is anticipated that this variable will have a positive and statistically significant effect on net FDI flows to the region.

Turning to the qualitative variables, dummy variable D1 equals 1 for the economic crises years associated with the onset and aftermath of the debt crisis (1982-83), the negative spillover effects resulting from the Mexican Peso crisis of 1994-1995, and the sharp fall in economic activity as a result of the 2008-2009 economic and financial debacle in the U.S. It is expected to have a negative and significant effect on net FDI flows. D2 is set equal to 1 for the 1991-93 and 1996-1999, and 2011-2013 periods (acceleration of foreign investment flows to the region as a result of push factors in the developed nations and the consolidation of market-based, outward-oriented strategies of economic growth and development that the major countries of the region began to implement following the Brady Plan. It is expected to be positive and significant.

\subsection{Data}

The data consists of 9 cross-sectional units, denoted $\mathrm{i}=1, \ldots, 9$, observations at each of 35 periods, $\mathrm{t}=1, \ldots, 35$, for a total of 315 observations. The data could not be extended beyond 2014 because of unavailability of data for key variables such as education and public investment. Most of the economic data (including foreign direct investment) used in this study were obtained from official sources such as various issues of ECLAC's Statistical Yearbook for Latin America and the Caribbean (Santiago: United Nations), UNCTAD's World Investment Report (Geneva: United Nations). The data for public investment refers to fixed capital formation; i.e., it excludes financial investment. According to the International Finance Corporation (IFC), the data has been obtained from Everhart and Sumlinski (1999) and the I.F.C.'s Trends in Private Investment in Developing Countries: Statistics for 1970-2000. Finally, the data for the economic freedom index was obtained from various Annual Reports of the Economic Freedom of the World published by The Fraser Institute.

\footnotetext{
${ }^{7}$ Economic freedom should not be confused with political and civil liberties. Countries may confer upon their citizens a substantial amount of political and civil liberty in the form of fair and competitive elections and freedom of the press, but still pursue policies that are inimical to economic freedom such as high levels of taxation and excessive government intervention and regulation.
} 


\subsection{Panel Unit Roots}

Panel data, just like univariate time series data, tend to be non-stationary. Non-stationary data exhibit trends over time, either deterministic and/or stochastic; in other words, their variances and covariances are not time invariant, thus generating misspecified or spurious results. It is therefore crucial to test for the presence of panel unit roots and determine the order of integration. If the panel variables are found to have the same order of integration, it will be necessary to determine if a unique long-term relationship exists among them via panel cointegration test.

Non-stationarity can be formally identified through testing for the presence of unit roots. This paper utilizes three panel-based unit root tests. The first test, proposed by Levin, Lin, and Chu (LLC, 2002), extends the Augmented Dickey-Fuller (ADF) test to panel data using the following model:

$$
\Delta Y_{i t}=\gamma Y_{i t-1}+\sum \theta_{i j} \Delta Y_{i t-j}+\alpha_{m i} d_{m t}+u_{i t}
$$

$Y_{i t}$ refers to each pooled variable; $u_{i t}$ is the mutually independent error terms; and $\gamma$ is equal to $\rho-1$. Heterogeneity is allowed through the component $\alpha_{m i} d_{m t}$, which represents exogenous variables of individual fixed effects and country-specific time effects. The lag order for the difference terms is also permitted to vary. $\gamma$, however, is assumed to be homogenous or the same across all cross section units.

Similar to the ADF test, the null hypothesis is that $\gamma$ is equal to zero, or the variable is non-stationary. The alternative hypothesis is that $\gamma$ is less than zero, or the variable is stationary. Since $\gamma$ is same for all cross-sections, when the null hypothesis is rejected in the LLC test, we conclude that each time series is stationary for all seven countries. The LLC test hence fails to account for a case where the series is stationary in only some countries and not in others. The Im, Pesaran, and Shin (IPS, 1997) test addresses this drawback by allowing $\gamma$ to vary across the cross-sectional units. The IPS test is thus less restrictive and tests the null of non-stationarity against the alternative that stationarity is present in at least one of the cross sections over time.

The LLC and IPS test results were confirmed using the Hadri test (2000). Unlike the other two tests, the Hadri test uses stationarity as its null hypothesis. The results are presented in Table 3 below. All variables exhibit a unit root in level form at the 5 percent level of significance. The confirmatory Hadri test suggests that they are non-stationary in level form and stationary in first difference.

\subsection{Panel Cointegration}

Given that all the series in the panel are integrated of order one, it is necessary to determine if a unique long-term relationship exists among the variables via panel cointegration test. This study utilizes the Pedroni methodology (1999) because it allows for considerable heterogeneity in the data. The test utilizes the following model:

$$
Y_{i t}=a_{i}+\delta_{t}+\sum_{m=1}^{M} \beta_{m i} X_{m i t}+u_{i t}
$$

allowing for multiple regressors, represented as $m$. The first two components represent individual-specific fixed effects and time trends. The methodology also allows the long-run cointegrating vectors and error terms to vary across cross-sectional units. The Pedroni test employs a total of seven statistics, four of which are panel statistics and the rest are group statistics. The panel statistics capture the within-dimension effects by pooling the AR coefficients across cross-sections to test for unit roots on the residuals. The group panel statistics capture the between-dimension effects by pooling the AR coefficients for each member.

The null hypothesis is that of no cointegration. If it is rejected in the case of panel statistics, we can conclude that the variables in question are cointegrated for all countries. In the less restrictive group panel case, we conclude that the panel variables are cointegrated for at least one country. The reported results in Table 4 below, both panel ADF and PP test statistics and group PP statistics, suggest strong evidence for the alternative hypothesis of cointegration or a long-term relationship.

\subsection{FMOLS Results}

Having established that the panel series are non-stationary but also cointegrated, we turn to generating long-run estimates for Equation (1). Following the lead of Pedroni (2000), this paper applies the group-mean panel fully modified OLS (FMOLS) technique to Equation (1) above. The FMOLS estimate of the $\beta$ population parameter for country $i$ is mathematically represented as:

$$
\hat{\beta}_{i}^{*}=\left(X_{i}^{\prime} X_{i}\right)^{-1}\left(X_{i}^{\prime} y_{i}^{*}-T \delta\right)
$$

where $y_{i}^{*}$ is the transformed variable; $T$ is the number of time periods; and $\delta$ is the adjustment parameter for serial correlation. The bias induced by endogeneity is eliminated by applying a semi-parametric correction into the model. Thus, as Pedroni contends, the FMOLS estimators are "extremely accurate even in panels with very heterogeneous 
serial correlation dynamics, fixed effects and endogenous regressors". ${ }^{8}$

The FMOLS results are presented in Table 5 below. For example, the LGDP variable is highly significant in all specifications, suggesting that a 1 percent increase in real GDP in the current period increases the share of net FDI flows to the region 1.88 percent, ceteris paribus (see, e.g., specification without dummies). The volatility in this variable, as measured by the period standard deviation in GDP, is negative and highly significant (see specification with period standard deviations). The credit variable (CR) is positive and significant in all the reported estimations, indicating that an easing of the credit constraint is an important determinant of net FDI flows to the region. This is not an altogether surprising result in view of the fact that most of the credit granted by the banking sector in Latin America has traditionally been channeled to large enterprises, including subsidiaries of TNC's operating in key sectors of the countries in question (see Aliber, 1970; and Mortimore, 2003). As anticipated, the education variable has a positive and significant effect in all specifications (with and without dummies). For example, the estimate in the equation with dummies suggests that a one percentage point increase in the current ratio of government expenditures on education to GDP will generate an increase of 0.18 percent in the share of net FDI flows to the region, ceteris paribus.

The negative and significant sign for the public investment variable in all specifications suggests that increases in this variable, ceteris paribus, tend to crowd out net FDI flows to the region for the period in question. This unexpected result may be due to the fact that we are not able to isolate the effect of increased investment spending on economic infrastructure per se given the level of aggregation of the data. It may also be a "statistical artifact" generated from our inability to effectively control for the deleterious impact of the IMF-sponsored stabilization programs on public investment spending during the 1980s, 1990s and 2000s in several of the countries included in this study.

Turning to the real exchange rate variable, it can be seen that it has a negative and significant effect on FDI flows; thus, on a net basis, a real depreciation of the currency has a negative effect on the profitability of export-oriented sectors where FDI flows have been concentrated in recent years. The equation with SDREX variable, designed to capture the impact of the volatility of REX (uncertainty) on FDI flows to the region, also has a negative and highly significant effect on FDI flows. The debt-service variable also has a negative effect in all reported estimations were it is included, but it is marginally significant in the specification with and without dummies.

As expected, the economic freedom variable has a positive and highly significant effect all specifications. The interpretation of this variable should be undertaken with care given its inherently subjective nature, but the estimate does suggest that a "better" macroeconomic environment and legal-institutional framework is conducive to attracting net FDI flows to the region. Lastly, the dummy variables reported in Table 5 also have their anticipated and significant effects at the 5 percent level. It should also be noted that eq. (1) was estimated with an interaction term (not reported in Table 5 but available upon request) which suggests that the market-based, outward-oriented reforms of the early 1990s and 2000s further enhanced the impact of market size on the share of net FDI flows to Latin America by an additional 0.33 percent, ceteris paribus.

\section{Summary and Conclusions}

This paper utilized John Dunning's OLI framework to identify some of the major economic and institutional determinants of FDI flows to Latin America. Next, it reported evidence which suggests that net FDI flows to Latin America during the decade of the 1990s and 2000s have been substantial, both in relation to GDP and domestic capital formation. Another favorable trend in recent years is the high proportion of FDI flows directed to Greenfield investments, viz., in new enterprises in leading sectors, as opposed to cross-border mergers and acquisitions that were relatively more important during the privatization frenzy that hit the region during the 1990s (see UNCTAD, 2017). However, the evidence also indicates that reverse flows in the form of profits and dividend remittances have continued to grow into the decade of the 2000s both in absolute and relative terms--not to mention unreported transfers. Thus, the contribution of net FDI to the financing of capital formation, although increasing, is far less than advertised when these reverse flows are included. This is a worrisome trend and brings into question the overly liberal short-run policies designed to attract FDI flows to the region, such as in the case of Chile where the country eliminated all taxes on repatriated profits and dividends, as well as minimum stay and export requirements during the 1990s (see Edwards, 1999; and Cordero, 2010).

\footnotetext{
${ }^{8}$ A GMM estimator was not used because they are usually employed when one has no knowledge of the underlying distribution. In a long panel, such as the one utilized in this paper, the errors are normally distributed, and the use of the FMOLS estimator is warranted. In fact, Pedroni (2000) has shown, via small sample Monte Carlo simulations, that the bias (and sampling variance) of the group mean FMOLS estimator (based on the "between" dimension of the panel) is very small, even in extreme cases when both the $\mathrm{N}$ and $\mathrm{T}$ dimensions are as small as $\mathrm{N}=10$ and $\mathrm{T}=10$ (and they become insignificant as the time dimension increases).
} 
This study performed panel unit root and panel cointegration tests on the relevant panel variables and determined that a non-spurious (cointegrated) relationship exists among the variables. This is a highly important finding because it indicates that the variables of the pooled model have a stable long-term relationship that keeps them in proportion to one another. In turn, the FMOLS regressions suggest that market size has a positive and statistically significant effect on net FDI flows to the region, while its period standard deviation (a volatility proxy) has a negative and statistically significant effect. These results are in line with those of most studies which find that TNCs are attracted to markets that exhibit steady and positive growth. The credit variable and the education variable also have their expected positive and significant effect on net FDI flows, while the debt-service ratio and standard deviation of the real exchange rate have their anticipated negative signs and are significant in most regressions, albeit at the marginal level for the debt-service ratio variable. The institutional variables, as captured by the dummy variables and the Fraser Institute's economic freedom variable, have their anticipated effects, with the economic freedom variable having a positive and economically important effect on net FDI flows. The only variable with a somewhat unexpected (negative) and significant sign is public investment as a percentage of GDP. This may be due to a number of factors, ranging from data problems that prevent us from isolating the effect of infrastructure investment spending per se to the unprecedented reduction as well as the variability in the ratio of public investment to GDP in recent years.

From a policy standpoint, the results in this paper are consistent with those of other studies cited above, and they suggest that policies that promote sustained economic growth, investments in education, macroeconomic stability--particularly GDP and exchange rate stability--and a legal-institutional framework conducive to business activity, are likely to attract FDI flows to the region on a long-term basis.

Table 3. Summary of Panel Unit Root Test Results: 1980-2014

\begin{tabular}{c|c|c|c|c|c|c}
\hline \multirow{2}{*}{ Variable } & \multicolumn{3}{|c|}{ Levels } & \multicolumn{3}{c}{ Differences } \\
\cline { 2 - 6 } & LLC & IPS & Hadri & LLC & IPS & Hadri \\
\hline$F D I$ & 1.02365 & 0.0114 & $8.6311^{* *}$ & $-15.1933^{* *}$ & $-17.2429^{* *}$ & -0.0451 \\
\hline$L G D P$ & 1.68822 & 5.2497 & $10.4489^{* *}$ & $-13.449^{* *}$ & $-12.5709 * *$ & -0.3373 \\
\hline$C R$ & 0.67325 & 0.7577 & $5.0690^{* *}$ & $-14.3564^{* *}$ & $-14.8797^{* *}$ & -1.3961 \\
\hline$G I R$ & $-2.7308^{*}$ & $-1.7632^{*}$ & $6.1352^{* *}$ & $-16.6716^{* *}$ & $-15.0882^{* *}$ & 1.6389 \\
\hline$G E D$ & 0.1811 & 0.5608 & $7.1730^{* *}$ & $-13.5183^{* *}$ & $-12.9248^{* *}$ & 0.6866 \\
\hline$D S$ & $-2.7657^{*}$ & $-2.8208^{*}$ & $8.4817^{* *}$ & $-24.3050^{* *}$ & $-25.7197^{* *}$ & -0.8012 \\
\hline$R E X$ & -1.6609 & -1.6360 & $3.8986^{* *}$ & $-11.2588^{* *}$ & $-11.4995^{* *}$ & 0.2085 \\
\hline$E F$ & -1.5047 & 0.0935 & $5.9121^{* *}$ & $-11.3642^{* *}$ & $-10.8579^{* *}$ & 0.0493 \\
\hline
\end{tabular}

Note: *significant at 10 percent level; **significant at 5 percent level

Table 4. Summary of Pedroni Cointegration Test Results: 1980-2014

\begin{tabular}{c|c|c|c|c}
\hline & \multicolumn{2}{|c|}{ Without EF Variable } & \multicolumn{2}{c}{ With EF Variable } \\
\hline & Panel & Group & Panel & Group \\
\hline v-statistic & -1.240290 & - & -1.302291 & - \\
\hline rho-statistic & 1.071109 & 1.532310 & 0.377855 & 1.046032 \\
\hline PP-statistic & $-2.508132^{* *}$ & $-4.259727^{* *}$ & $-4.249740^{* *}$ & $-5.466853^{* *}$ \\
\hline ADF-statistic & $-2.546437^{* *}$ & $-1.848640^{*}$ & $-3.001816^{* *}$ & $-1.893774^{*}$ \\
\hline
\end{tabular}

Note: *significant at 10 percent level; $* *$ significant at 5 percent level 
Table5. FMOLS Results: 1980-2014

\begin{tabular}{|c|c|c|c|c|c|c|}
\hline \multirow[t]{2}{*}{ Variables } & \multicolumn{2}{|c|}{ Without Dummy Variables } & \multicolumn{2}{|c|}{ With Dummy Variables } & \multicolumn{2}{|c|}{$\begin{array}{c}\text { With Standard Deviation } \\
\text { Variables }\end{array}$} \\
\hline & Coefficient & t-Statistic & Coefficient & t-Statistic & Coefficient & t-Statistic \\
\hline$L G D P$ & 1.8827 & $9.66 * *$ & 1.9236 & $9.67 * *$ & 2.099 & $14.54 * *$ \\
\hline$C R$ & 0.0897 & $2.48 * *$ & 0.0690 & $1.90 * *$ & 0.071 & $1.70^{*}$ \\
\hline GIR & -0.1691 & $-3.89 * *$ & -0.1048 & $-2.39 * *$ & -0.432 & $-8.61 * *$ \\
\hline$G E D$ & 0.1321 & $3.45 * *$ & 0.1753 & $4.56 * *$ & 0.201 & $4.88 * *$ \\
\hline$D S$ & -0.0293 & -0.59 & -0.0648 & $-1.30 *$ & 0.154 & $-2.65 * *$ \\
\hline$R E X$ & -0.1208 & $-3.34^{*}$ & -0.1336 & $-3.61 * *$ & --- & --- \\
\hline$E F$ & 0.0947 & $3.06^{*}$ & 0.0710 & $2.20 * *$ & 0.426 & $12.21 * *$ \\
\hline DI & --- & --- & -0.2778 & $-4.35 * *$ & --- & --- \\
\hline D2 & --- & --- & 0.9800 & $10.31 * *$ & --- & --- \\
\hline SDREX & --- & --- & --- & & -0.378 & $-6.12 * *$ \\
\hline \multirow[t]{2}{*}{$S D L G D P$} & --- & --- & --- & & -14.48 & $-21.70 * *$ \\
\hline & \multicolumn{2}{|c|}{$* 10$ percent level } & \multicolumn{2}{|c|}{$* * 5$ percent level } & & \\
\hline
\end{tabular}

\section{References}

Agosin, M. R. (ed.) (1995). Foreign Direct Investment in LatinAmerica, Inter-American Development Bank, USA.

Aliber, R. (1970). A Theory of Direct Foreign Investment, in Kindleberger. C.P. (ed.) The International Corporation: A Symposium. Cambridge, MA: MIT Press.

Bosworth, B. P., \& Collins, S. M. (1999). Capital Flows to Developing Economies: Implications for Savings and Investment. Brookings Papers on Economic Activity, 1, 143-180.https://doi.org/10.2307/2534664

Chang, H. J. (2008). Bad Samaritans. Bloomsbury Press, USA.

Chowdhury, A., \& Mavrotas, G. (2006). FDI and Growth: What Causes What? World Economy, 29(1), 9-19. https://doi.org/10.1111/j.1467-9701.2006.00755.x

Cypher, J. M., \& Dietz, J. L. (2014). The Process of Economic Development, Routledge, USA. https://doi.org/10.4324/9780203080580

De-Mello, L. R. J. (1997). Foreign Direct Investment in Developing Countries and Growth: A Selective Survey, Journal of Development Studies, 34, 1-34. https://doi.org/10.1080/00220389708422501

Dunning, J. H. (1988). Explaining International Production, London: Harper \& Collins.

ECLAC. (2006). Foreign Investment in Latin America and the Caribbean, 2005Report, Santiago, Chile: United Nations.

ECLAC. (2012). Economic Survey of Latin America and the Caribbean 2009-2010, Santiago, Chile: United Nations.

ECLAC. (2015-16). Economic Survey of Latin America and the Caribbean 2013-2015, Santiago, Chile: United Nations.

Economic Commission for Latin America and the Caribbean (ECLAC). (2008).Preliminary Overview of the Economies of Latin America and the Caribbean, Santiago, Chile: United Nations.

Edwards, S. (1999). How Effective are Capital Controls? Journal of Economic Perspectives, 13, 65-84. https://doi.org/10.1257/jep.13.4.65

Erden, L., \& Holcombe, R. G. (2005). The Effects of Public Investment on Private Investment in Developing Economies. Public Finance Review, 33, 575-602. https://doi.org/10.1177/1091142105277627

Everhart, S. S., \& Sumlinski, M. A. (2001). Trends in Private Investment in Developing Countries: Statistics for 1970-2000.International Finance Corporation, 44, The World Bank, USA.

Glen, J. D., \& Sumlinski, M. A. (1996). Trends in Private Investment in Developing Countries, International Finance Corporation, The World Bank, USA.

Hadri, K. (1999). Testing the Null Hypothesis of Stationarity Against the Alternative of a Unit Root in Panel Data with Serially Correlated Errors. Manuscript, Department of Economics and Accounting, University of Liverpool.

Im, K. S., Pesaran, M. H., \& Shin, Y. (2003). Testing for Unit Roots in Heterogeneous Panels. Journal of Econometrics, 
115, 53-74.https://doi.org/10.1016/S0304-4076(03)00092-7

Kumar, A. (2007). Does Foreign Direct Investment Help Emerging Economies? Economic Letter, 2, 1-8.

Levin, A., Lin, C. F., \& Chu, C. (2002). Unit Root Tests in Panel Data: Asymptotic and Finite-Sample Properties, Journal of Econometrics, 108, 1-24. https://doi.org/10.1016/S0304-4076(01)00098-7

Montecinos, J. A., \& Jose, A. C. (2010). Capital Controls and Monetary Policy in Developing Countries. Center for Economic and Policy Research, Washington, D.C., April, 1-33.

Mortimore, M. (2003). The Impact of TNC Strategies on Development in Latin America and the Caribbean. Published for Overseas Development Institute(UK), 1-23.

Pedroni, P. (1999). Critical Values for Cointegration Tests in Heterogeneous Panels with Multiple Regressors, Working Paper, Indiana University, July 25, 1999, pp. 1-19. Subsequently published in Oxford Bulletin of Economics and Statistics, 61, Special Issue.

Pedroni, P. (2000). Fully Modified OLS for Heterogeneous Cointegrated Panels. In: Advanced Econometrics, Vol. 15. Nonstationary Panels, Cointegration in Panels and Dynamic Panels: A Survey. Ed. by Baltagi, B.H. and C. Kao. https://doi.org/10.1016/S0731-9053(00)15004-2

Ram, R., \& Zhang, K. H. (2002). Foreign Direct Investment and Economic Growth: Evidence from Cross-Country Data for the 1990s.Economic Development and Cultural Change, 51, 205-215.https://doi.org/10.1086/345453

Ramasamy, B., \& Yeung, M. (2004). The European Union's Foreign Direct Investment into Indonesia: Determinants and Threats, in Kehal, H.S.Foreign Direct Investment in Developing Countries, Palgrave Macmillan, Ltd., USA, 134-153.https://doi.org/10.1057/9780230554412_8

Ramirez, M. D. (2005). Did Institutional Factors Enhance FDI Flows to Chile During the 1985-2001 Period? A Cointegration Analysis. Journal of Emerging Markets, 10, 18-29.

Ros, J. (1994). Financial Markets and Capital Flows in Mexico, in Ocampo, J.A. and Steiner, R. Foreign Capita lin Latin America, Inter-American Development Bank, USA.

Spitaler, E. (1971). A Survey of Recent Quantitative Studies of Long-Term Capital Movements.IMF Staff Papers,31, 189-217.

Stiglitz, J. E. (2003). Whither Reform? Towards a New Agenda for Latin America.Cepal Review, 80, 7-38.

UNCTAD. (2012 \& 2017). World Investment Reports 2012 \& 2017, New York: United Nations Conference on Trade and Development.

Vadlamannati, K., \& Tamazian, A. (2009). Growth Effects of Foreign Direct Investment and Economic Policy Reforms in Latin America, MPRA Paper No. 14133

Yeager, T, J. (1999). Institutions, Transition Economies, and Economic Development. Westview Press, USA.

Zhang, K. H. (2001). Does FDI Promote Economic Growth? Evidence from East Asia and Latin America, Contemporary Economic Policy, 19, 175-185. https://doi.org/10.1111/j.1465-7287.2001.tb00059.x

Zhuang, H. (2012). Modes of Entry and Regional Economic Growth: Evidence from US States. Journal of Applied Economics and Business Research, 2(4), 221-229.

\section{Copyrights}

Copyright for this article is retained by the author(s), with first publication rights granted to the journal.

This is an open-access article distributed under the terms and conditions of the Creative Commons Attribution license which permits unrestricted use, distribution, and reproduction in any medium, provided the original work is properly cited. 